\title{
Accurate modeling and maximum power point detection of photovoltaic module using a few collected data
}

\author{
Mohamed Abd-El-Hakeem Mohamed ${ }^{1}$, Almoataz Y. Abdelaziz ${ }^{2}$ \\ 1 Faculty of Engineering, Al-Azhar University, Qena, EGYPT \\ 2 Electrical Power \& Machines Department, Faculty of Engineering, Ain Shams University, Cairo, EGYPT
}

\begin{abstract}
This paper presents an algorithm for modeling and Maximum Power Point (MPP) detection of a Photo-Voltaic (PV) module. This algorithm requires less information to get an accurate model and MPP. Open circuit voltage $\left(\mathrm{V}_{\mathrm{OC}}\right)$ and short circuit current $\left(\mathrm{I}_{\mathrm{SC}}\right)$ of the PV module are required as inputs data. Both of them can be sampled from a reference PV Panel. A PV model and MPP are estimated via Newton-Raphson (NR) method. Fractional $V_{O C}$ and $I_{S C}$ method and simplified method are used for detecting the starting values of MPP and model parameters of a PV panel respectively. Then, the NR method is applied to calculate the accurate values of MPP and model parameters of it. Determination of MPP enables the PV system to deliver maximum available power. Verification of this algorithm is accomplished through building it in MATLAB. Then, it is tested for different manufacturer modules at different operating conditions.
\end{abstract}

Keywords: MPP; PV model, Accurate model; Newton-Raphson.

DOI: http://dx.doi.org/10.4314/ijest.v10i2.1

\section{Introduction}

PV systems are the most important renewable energy conversion systems due to a continuously reduction in their energy production cost (Kannan et al., 2006; Emmott et al., 2011; Bazilian et al., 2013). Also, they have the ability to product electrical energy during less time. So, the installed capacity of PV systems is increasing continuously (Masson et al., 2013). Estimation of a PV model is important in the fabrication, designing and performance prediction of the PV systems. Many methods are used for this purpose such as (Elshatter et al., 1997; Arab et al., 2004; De Soto et al., 2006; Carrero et al., 2007; Mellit et al., 2007; Celik and Acikgoz, 2007; Villalva et al., 2009). Conventional algorithms are investigated in (Carrero et al., 2007; Villalva et al., 2009; Celik and Acikgoz, 2007; Arab et al., 2004; De Soto et al., 2006). Also the intelligent algorithms are proposed in (Elshatter et al., 1997; Mellit et al., 2007). All of these models need to measure illumination and temperature to give good accuracy model.

Determination of MPP enables the PV system to deliver maximum available power. So, there are many investigations are proposed for this purpose such as (Abdelsalam et al., 2011; Jain and Agarwal, 2007; Kok Soon et al., 2013; Kamarzaman and Tan, 2014; Sera et al., 2013; Chun and Kwasinski, 2011; Huynh et al., 2013; Hohm and Ropp, 2003; Sher et al., 2015; Salam et al., 2013; Bai et al., 2014; Ishibashi et al., 2008; Chegaar et al., 2003; Faranda and Leva, 2008; López-Lapeña et al., 2010; Khezzar et al., 2009; Simjee and Chou, 2008; Dondi et al., 2008; Bai et al., 2014; Walker, 2001; Ma et al., 2013; Roman et al., 2006; Bahgat et al., 2005; El-Sayed and Leeb, 2014; Enslin et al., 1997; Noguchi et al., 2002). The simplest methods (open circuit voltage method and short circuit method are presented) in (Enslin et al., 1997; Noguchi et al., 2002) which are easy in implementation, but these methods have less accuracy. Many studies have been carried out via Perturb and Observe (P\&O) algorithm and its modification such as those given in (Abdelsalam et al., 2011; Jain and Agarwal, 2007). P\&O algorithm failed due to rapidlyvarying in the solar radiation, also it may take more time for convergence process because it depends on initial guess. IncrementalConductance (IC) method is proposed for MPP estimation (Kok Soon et al., 2013). Although IC MPPT is better than the (P\&O) 
(Ramani et al., 2017) but its response is poor in the steady-state operation. Although, many improvements are proposed on the (P\&O) and IC (Huynh et al., 2013; Hohm and Ropp, 2003; Sher et al., 2015), still there is a bad oscillatory behavior.

The MPP estimation process can be carried out by using Soft Computing (SC) (Salam et al., 2013). The most common SC-MPP algorithms are the Artificial Neural Network (ANN) and Fuzzy Logic (FL) (Bahgat et al., 2005; El-Sayed and Leeb, 2014). Soft computing algorithms are more efficient than IC and $\mathrm{P} \& \mathrm{O}$, but they need large data for training and periodic tuning. In Walker, (2001), MATLAB-PV modeling and MPP estimation has been presented. But, it requires insolation and temperature, for detecting $\mathrm{V}$ and I vectors. Ref. (Ma et al., 2013) presented an MPP DEM which works with the variety of atmospheric conditions. This method gives acceptable speed and accuracy, but it gives approximate MPP and also, temperature and solar radiation are required as input data.

In this paper, an algorithm is proposed to achieve two objectives simultaneously. These are the estimation of an accurate model and MPP of a PV module. The proposed algorithm uses $\mathrm{V}_{\mathrm{OC}}$ and $\mathrm{I}_{\mathrm{SC}}$ only as input data. Fractional $\mathrm{V}_{\mathrm{OC}}$ and $\mathrm{I}_{\mathrm{SC}}$ method and simplified method are used for detecting the starting values of MPP and the model parameters of a PV panel respectively. These values are near from the desired. So, the obtained solution via NR method is converged quickly. Verification of this algorithm is accomplished through building it in MATLAB. Then, it is tested for different manufacturer modules at different operating conditions.

\section{Problem Description}

The most common equivalent circuit of the PV cell is represented as shown in Fig. 1

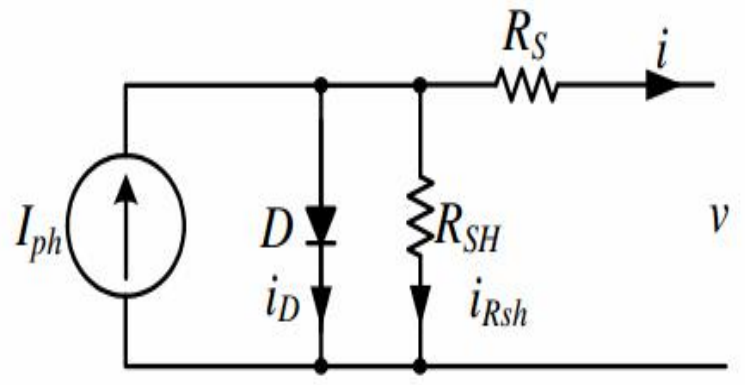

Fig. 1 Equivalent circuit of a photovoltaic cell using the single exponential module

The V-I characteristic of a PV panel based on the single exponential model is:

$$
I=I_{p h}-I_{o}\left(e^{x_{1}=I_{p h}}-1\right)-\frac{V+I R_{s}}{R_{s h}}=f_{i}
$$

or

$$
V=I_{p h} R_{s h}-I_{o} R_{s h}\left(e^{\frac{V+I R_{s}}{N_{s} V_{t}}}-1\right)-I R_{s h}-I R_{s}=f_{v}
$$

Equation (1) can be written as.

$$
I=x_{1}-x_{2}\left(e^{x_{4} V+I x_{5}}-1\right)-x_{3}\left(V+\frac{I x_{5}}{x_{4}}\right)=f_{i}
$$

Where

$$
x_{1}=I_{p h}, x_{2}=I_{o}, x_{3}=\frac{1}{R_{s h}}, x_{4}=\frac{1}{N_{s} V_{t}}, x_{5}=R_{s} x_{4}
$$

In order to calculate the PV model parameters (x1:x5) and detect Maximum Power Point $\left(x 6=I_{m} ; x 7=V_{m}\right)$ of a PV module, the current and the voltage at key operational point (the short-circuit point, the open-circuit point, and the maximum power point) are used as follow:

At short-circuit point, $\mathrm{V}=0, \mathrm{I}=\mathrm{Isc}$ :

$$
f_{1}=I_{s c}-f_{i}\left(I=I_{s c}, V=0\right)=I_{s c}-x_{1}+x_{2}\left(e^{I_{s c} x_{5}}-1\right)+x_{3}\left(\frac{I_{s c} x_{5}}{x_{4}}\right)=0
$$

from the slope of the I-V curve at the short circuit current point (Chegaar et al., 2003) 


$$
f_{2}=x_{5}+\frac{\partial f_{i}}{\partial V_{i}} \mid\left(I=I_{s c}, V=0\right)=0
$$

At open circuit point, $\mathrm{V}=\mathrm{Vo}, \mathrm{I}=0$ :

$$
f_{3}=0-f_{i}\left(I=0, V=V_{O C}\right)=-x_{1}+x_{2}\left(e^{x_{4} V_{O C}}-1\right)-x_{3}\left(V_{O C}\right)=0
$$

from the slope of the I-V curve at the open circuit point (Sera et al., 2013)

$$
f_{4}=\frac{x_{5}}{x_{4}}+\frac{\partial f_{v}}{\partial I} \mid\left(I=0, V=V_{O C}=0\right)=0
$$

At maximum power point MPP, $x_{6}=I_{m}, x_{7}=V_{m}$

$$
f_{5}=I_{m}-f_{i}\left(I=I_{m}, V=V_{m}\right)=x_{1}-x_{2}\left(e^{x_{4} V_{m}+I_{m} x_{5}}-1\right)-x_{3}\left(V_{m}+\frac{I_{m} x_{5}}{x_{4}}\right)=0
$$

Where

$$
P=f_{i} V
$$

An additional equation can be derived using the fact that is on the P-V characteristic of the panel, at the MPP, the derivative of power is zero.

$$
\begin{aligned}
& f_{6}=\frac{\partial P}{\partial I} \mid\left(I=x_{6}, V=x_{7}\right)=0 \\
& f_{7}=\frac{\partial P}{\partial V} \mid\left(I=x_{6}, V=x_{7}\right)=0
\end{aligned}
$$

Equations (4-11) can be expressed in the compact form as follow:

$$
f(x, u)=0
$$

Where

$$
\begin{aligned}
& x=\left[\begin{array}{lllllll}
x_{1} & x_{2} & x_{3} & x_{4} & x_{5} & x_{6} & x_{7}
\end{array}\right] \\
& f=\left[\begin{array}{lllllll}
f_{1} & f_{2} & f_{3} & f_{4} & f_{5} & f_{6} & f_{7}
\end{array}\right] \\
& u=\left[\begin{array}{llll}
I_{S C} & V_{O C}
\end{array}\right]
\end{aligned}
$$

\section{Choosing Starting Values for Newton-Raphson Computation of MPP and PV Model Parameters}

The Newton-Raphson- method requires appropriate initial guesses. This may cause the final convergence may not be guaranteed or may delay the MPP execution process. We have suggested the following method for getting optimal starting points for NewtonRaphson

3.1 Choosing Starting Values of MPP

Under any given environmental condition, the current at MPP $(\mathrm{Im})$ has approximately a linear relation with short-circuit current (Isc) as expressed in the below equation

$$
\begin{array}{r}
I_{m} \propto I_{s c} \\
\therefore I_{m}=K_{S C} I_{s c}
\end{array}
$$

where $\mathrm{k}$ is the constant of proportionality. Value of $\mathrm{k}$ is unique for different PV modules. Typically, it varies from 0.72 to 0.92 . Since it is an approximation, it does not track the real MPP. However, the tracking speed is fast with a reasonable efficiency up to 90\% (Faranda and Leva, 2008). The FOCV method exploits the nearly linear relationship between a PV module's open-circuit voltage (VOC) and its voltage at the MPP (Vmp) under varying irradiance and temperature levels (López-Lapeña et al., 2010). The FOCV technique exploits the nearly linear relationship between the Vmp of a solar cell and its VOC as

$$
\begin{array}{r}
V_{m} \propto V_{O C} \\
\therefore V_{m}=K_{O C} V_{O C}
\end{array}
$$


To include the effects of the environment, e.g. temperature and irradiance on the values of (Isc, Voc) (Khezzar, 2009).

$$
\begin{array}{r}
\mathrm{I}_{\mathrm{sc}}=\frac{\mathrm{G}}{\mathrm{G}_{\mathrm{ref}}} \mathrm{I}_{\mathrm{sc}-\mathrm{ref}}+\mathrm{K}_{\mathrm{i}} \Delta \mathrm{T} \approx \frac{\mathrm{G}}{\mathrm{G}_{\mathrm{ref}}} \mathrm{I}_{\text {sc }-\mathrm{ref}} \\
V_{O C}=V_{O C-r e f}+\mathrm{K}_{\mathrm{v}} \Delta \mathrm{T}+V_{t} \ln \left(\frac{\mathrm{G}}{\mathrm{G}_{\mathrm{ref}}}\right) \\
\therefore \frac{\mathrm{G}}{\mathrm{G}_{\mathrm{ref}}} \approx \frac{\mathrm{I}_{\mathrm{sc}}}{\mathrm{I}_{\mathrm{sc}-\mathrm{ref}}} \\
\therefore \Delta \mathrm{T}=\frac{\Delta V_{O C}-V_{t} \ln \left(\frac{\mathrm{I}_{\mathrm{sc}}}{\mathrm{I}_{\mathrm{sc}-\mathrm{ref}}}\right)}{\mathrm{K}_{\mathrm{v}}}
\end{array}
$$

From quations (18-24), we can deduce that

$$
\begin{aligned}
& \mathrm{x}_{6}^{(0)}=\mathrm{I}_{\mathrm{m}}=\frac{\mathrm{I}_{\mathrm{sc}}}{\mathrm{I}_{\mathrm{sc}-\mathrm{ref}}} \mathrm{I}_{\mathrm{m}-\mathrm{ref}}+\mathrm{K}_{\mathrm{i}} \frac{\Delta V_{O C}-V_{t} \ln \left(\frac{\mathrm{I}_{\mathrm{sc}}}{\mathrm{I}_{\mathrm{sc}-\mathrm{ref}}}\right)}{\mathrm{K}_{\mathrm{v}}} \\
& \mathrm{x}_{7}^{(0)}=V_{m}=V_{m-r e f}+\mathrm{K}_{\mathrm{m}} \frac{\Delta V_{O C}-V_{t} \ln \left(\frac{\mathrm{I}_{\mathrm{sc}}}{\mathrm{I}_{\mathrm{sc}-\mathrm{ref}}}\right)}{\mathrm{K}_{\mathrm{v}}}+V_{t} \ln \left(\frac{\mathrm{I}_{\mathrm{sc}}}{\mathrm{I}_{\mathrm{sc}-\mathrm{ref}}}\right)
\end{aligned}
$$

Where

$\mathrm{Ki}, \mathrm{Kv}, \mathrm{Km}$ Temperature coefficient of the short-circuit current - open-circuit voltage and maximum voltage respectively. 3.2 Choosing Starting Values of PV Parameters

The initial estimation of PV parameters is critical because a bad starting point can compromise the convergence of the NewtonRaphson's method. The initial values of these parameters are estimated by using the simplified method (Khezzar et al., 2009). In this method some of the approximations are applied as (Isc=Iph, and $\mathrm{Rsh}=\infty$, after simplification of equations (4-10) we obtain:

$$
\begin{array}{r}
\mathrm{x}_{1}^{(0)}=\mathrm{I}_{\mathrm{sc}} \\
\mathrm{x}_{4}^{(0)}=\frac{\frac{\mathrm{I}_{\mathrm{sc}}}{\mathrm{I}_{\mathrm{sc}}-\mathrm{x}_{6}^{(0)}}+\ln \left(1-\frac{\mathrm{x}_{6}^{(0)}}{\mathrm{I}_{\mathrm{sc}}}\right)}{2 \mathrm{x}_{7}^{(0)}-V_{O C}} \\
\mathrm{x}_{5}^{(0)}=\frac{\mathrm{x}_{2}^{(0)}=\mathrm{x}_{1}^{(0)} e^{-\mathrm{x}_{4}^{(0)} V_{O C}}}{\mathrm{x}_{6}-\mathrm{x}_{7}^{(0)}+\ln \left(1-\frac{\mathrm{x}_{6}^{(0)}}{\mathrm{I}_{\mathrm{sc}}}\right)} \\
\mathrm{x}_{3}^{(0)}=\frac{\mathrm{x}_{1}^{(0)}-\mathrm{x}_{2}^{(0)} e^{\mathrm{x}_{5}^{(0)} I_{S C}}}{V_{O C}}
\end{array}
$$




\section{The Proposed Procedure for Accurate Modeling and Maximum Power Point Detection of Photovoltaic Module using a Few Collected Data}

The determination of unknown parameters x1:x7 (MPP and model parameter) of the PV module at various operation conditions is described in the following steps:-

Step 1: detection of the inputs of the algorithm (open circuit and short circuit only) which can be measured by using different methods (Sher et al., 2015; Simjee and Chou, 2008; Dondi et al., 2008; Bai et al., 2014).

Step 2: estimate of the initial MPP and model parameters $\left(\mathrm{x}^{(\mathrm{v})}\right)$ by using equations $22-28$.

Step 3: The elements of the resulting Jacobian matrix (J) are obtained by differentiating equation (12) as follows:

$$
J \Delta x=\Delta f(x, u)
$$

Where

$$
\begin{array}{r}
J_{i j}=\frac{\partial f_{i}}{\partial x_{j}} \\
\Delta x=J^{-1} \Delta f(x, u)
\end{array}
$$

The correction values can be calculated as follows:

$$
\begin{gathered}
\Delta f^{i t}=0-f^{i t-1} \\
x^{i t}=x^{i t-1}+\Delta x
\end{gathered}
$$

Step 4: The process of iteration (equations 33-36) are repeated until the values of these corrections are minimized.

\section{Results and Discussion}

The previous section describes the proposed algorithm construction of a PV panel model. This algorithm has been implemented in MATLAB, in order to verify it at the different values open circuit and short circuit which are varied corresponding to temperature and irradiance conditions. The proposed model was tested using different manufacturer data sheets as in Table1.

Table 1. Datasheet for KC200GT solar module sand SP75 solar module at 25 CC, AM1.5, and 1000 W/m2

\begin{tabular}{|l|l|l|}
\hline Parameter & $\begin{array}{l}\text { KC200GT solar } \\
\text { Module (Shell, 2018) }\end{array}$ & $\begin{array}{l}\text { SP75 solar } \\
\text { Module } \\
2018)\end{array}$ \\
\hline $\mathrm{Pm}$ & $200 \mathrm{~W}$ & $75 \mathrm{~W}$ \\
\hline $\mathrm{Vm}$ & $26.3 \mathrm{~V}$ & $17 \mathrm{~V}$ \\
\hline $\mathrm{Im}$ & $7.61 \mathrm{~A}$ & $4.4 \mathrm{~A}$ \\
\hline $\mathrm{Voc}$ & $32.9 \mathrm{~V}$ & $21.7 \mathrm{~V}$ \\
\hline $\mathrm{Isc}$ & $8.21 \mathrm{~A}$ & $4.8 \mathrm{~A}$ \\
\hline $\mathrm{kV}$ & $-0.123 \mathrm{~V} / \mathrm{oC}$ & $-76 \mathrm{mV} / \mathrm{oC}$ \\
\hline $\mathrm{Ki}$ & $+3.18 \mathrm{~mA} / \mathrm{oC}$ & $+2 \mathrm{~mA} / \mathrm{oC}$ \\
\hline number of cells $(\mathrm{ns})$ & 54 & 36 \\
\hline
\end{tabular}

The determination of unknown parameters $\mathrm{x} 1: \mathrm{x} 7$ (MPP and model parameter) of the PV module at various operating conditions is described in pervious section The proposed model is tested for different manufacturer modules under different condition. These parameters are used to plot a voltage-cureent characterstic of a PV moduel according to eq 3. The calculated data have been compared to the characteristics and values provided by the product data-sheet.

It can be seen from Figs. (2-7) that the calculated V-I curves based on the proposed PV model are in very good agreement with the data-sheet values for SP75 (mono-crystalline silicon) solar module and KC200GT (multicrystal).

To evaluate the accuracy of the proposed model, the corresponding normalized root mean square error percentage [nRMSE( $\%)$ ] is calculated at different conditions and calculated by

$\mathrm{nRMS} \%=\frac{\sqrt{\frac{1}{\mathrm{~N}} \sum_{1}^{\mathrm{N}}\left(\mathrm{E}_{\mathrm{i}}-\mathrm{T}_{\mathrm{i}}\right)^{2}}}{\sqrt{\frac{1}{\mathrm{~N}} \sum_{1}^{\mathrm{N}}\left(\mathrm{T}_{\mathrm{i}}\right)^{2}}} * 100$ 
where $\mathrm{Ei}$ is the estimated value, and $\mathrm{Ti}$ is true values obtained from data sheet of KC200GT. Table 2 gives the evaluated nRMSE $(\%)$. As it can be seen from this Table 2, the proposed model has presented the good accuracy under different conditions. In addition, it is seen that the accuracy of the estimated values of maximum power are in good tolerance.

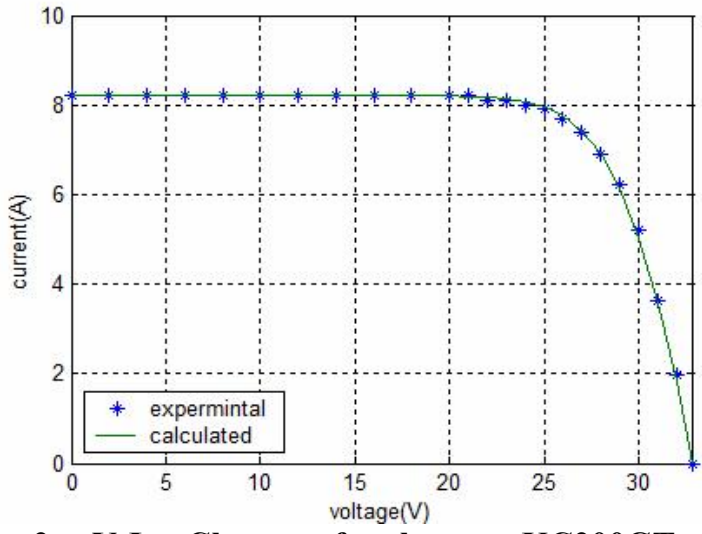

Fig. 2 V-I Char. of the KC200GT model (multicrystal) at $\mathrm{Vo}=32.9, \mathrm{Isc}=\mathbf{8 . 2 1}, \mathrm{G}=\mathbf{1 0 0 0}, \mathrm{T}=\mathbf{2 5}$

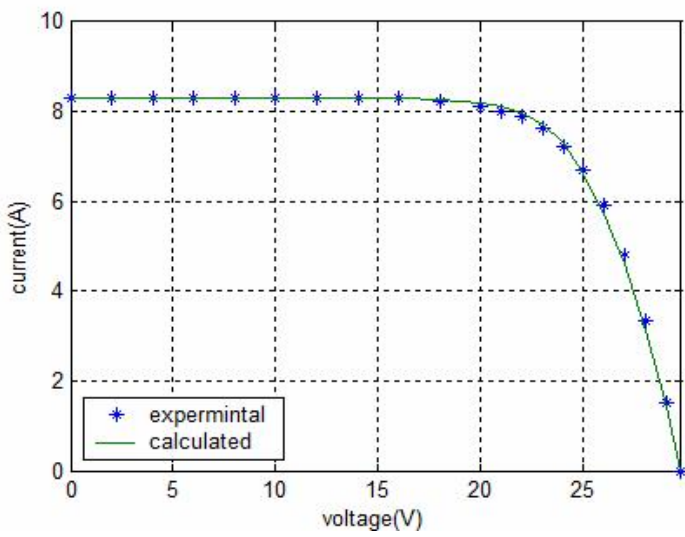

Fig. 3 V-I Char. of the KC200GT model (multicrystal) at $V_{0}=29.75, I s c=8.29, G=1000, T=50$

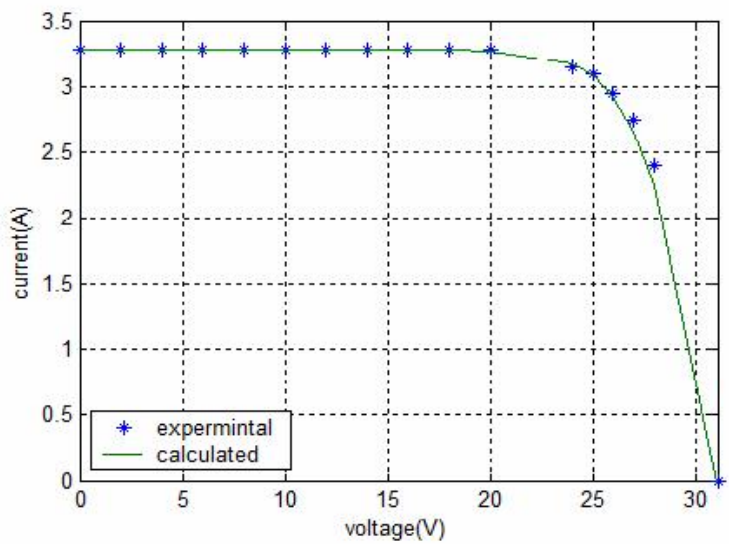

Fig. 4 V-I Char. of the KC200GT model (multicrystal) at $V_{0}=1.1, I s c=3.28, G=400, T=25$

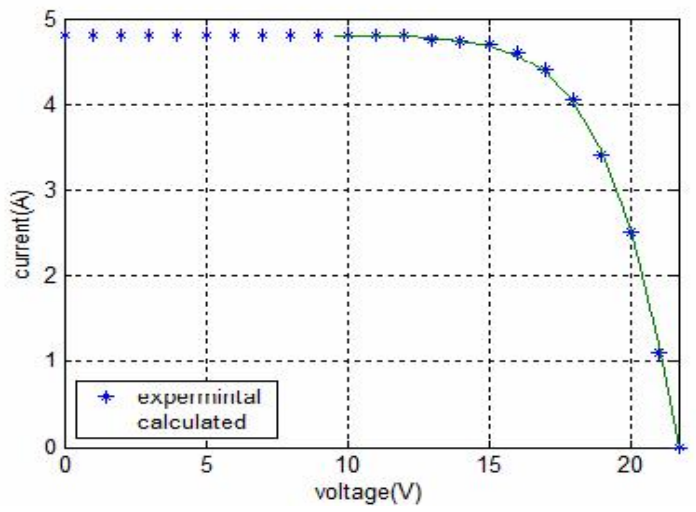

Fig. 5 V-I Char. of the shell SP75 model (monocrystalline silicon) at $V_{0}=21.7, I s c=4.8, G=1000, T=25$

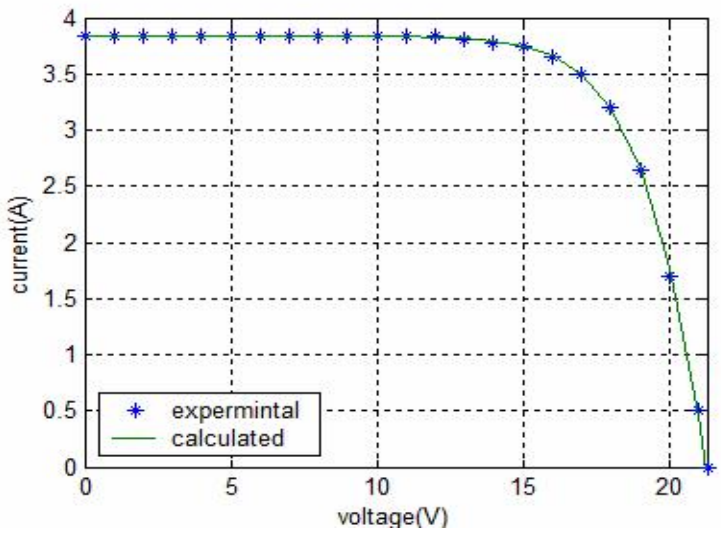

Fig. 6 V-I Char. of the shell SP75 model (monocrystalline silicon) at $\mathrm{Vo}_{0}=\mathbf{2 1 . 3} \mathrm{Isc}=\mathbf{3 . 8 4}, \mathrm{G}=\mathbf{8 0 0}, \mathrm{T}=\mathbf{2 5}$

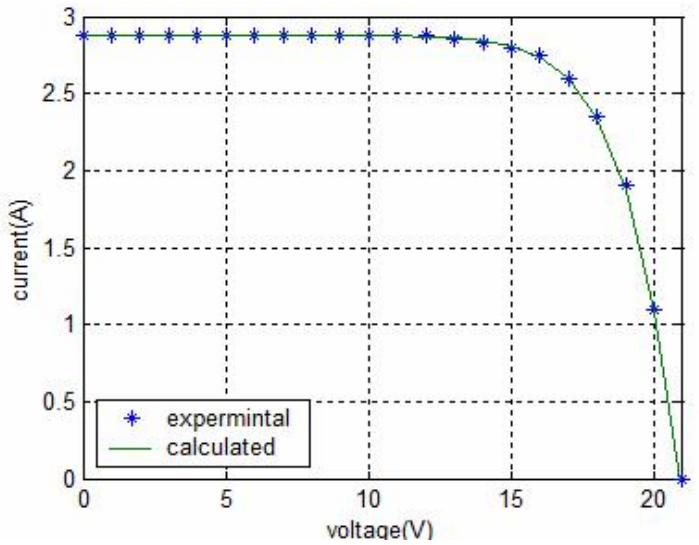

Fig. 7 V-I Char. of the shell SP75 model (monocrystalline silicon) at $\mathrm{Vo}_{\mathrm{o}}=\mathbf{2 1 . 0}, \mathrm{Isc}=\mathbf{2 . 8 8}, \mathrm{G}=\mathbf{6 0 0}$ 
Table 2. Evaluation of NRMSE(\%) for KC200GT Module

\begin{tabular}{|c|c|c|c|}
\hline VO & ISC & NRMSE(\%) & $\begin{array}{c}\text { ERROR\% OF MAX } \\
\text { POWER }\end{array}$ \\
\hline 32.9 & 8.21 & 0.75318 & 1 \\
\hline 31.1 & 3.28 & 1.5 & 0.07 \\
\hline 29.75 & 8.29 & 1.2 & 0.8 \\
\hline
\end{tabular}

Table 3 gives the evaluated nRMSE $(\%)$ corresponding to the theoretical I- V curves based on the proposed model and experimental data for SP75 at different environmental conditions. It is seen that the accuracy of the estimated values of maximum power are in good tolerance for SP75 at different environmental conditions. It can be observed that the theoretical I-V curves are sufficiently accurate for the experimental data. This proves the validity of the proposed parameter identification technique for PV modules.

Table 3. Evaluation of NRMSE(\%) for SP7 Module

\begin{tabular}{|c|c|c|c|}
\hline VO & ISC & NRMSE(\%) & $\begin{array}{c}\text { ERROR\% OF } \\
\text { MAX POWER }\end{array}$ \\
\hline 21.7 & 4.8 & 0.60547 & 0.41826 \\
\hline 21.0 & 2.88 & 1.0012 & 0.11714 \\
\hline 21.3 & 3.84 & 0.58 & 1.5 \\
\hline
\end{tabular}

The superitory of the proposed method over than other methods can be prsented as shown in Table 4. The proposed MPPT algorithm has an ability to detect MPP of any PV independent on its technologies and size. But, FL and ANN are module dependent. The proposed algorithm has the least value of MPP error compared with others algorithms. The proposed method requires measurement of the short circuit current and open circuit only where, the measuring of current and voltage is typically easier and more reliable than sensors that measure the light level.

Table 4: Comparison between Different Algorithms of MPP

\begin{tabular}{|l|l|l|l|l|l|l|l|}
\hline & $\begin{array}{l}\text { Fraction } \\
\text { Open circuit } \\
\text { voltage }\end{array}$ & $\begin{array}{l}\text { Fraction } \\
\text { Short circuit } \\
\text { current }\end{array}$ & P@O & I@C & ANN & FL & Proposed \\
\hline $\begin{array}{l}\text { PV array } \\
\text { dependent }\end{array}$ & No & No & No & No & Yes & Yes & No \\
\hline $\begin{array}{l}\text { Error \% in } \\
\text { MPP }\end{array}$ & $>10 \%$ & $>10 \%$ & $<5 \%$ & $<3 \%$ & $<2 \%$ & $<2 \%$ & $<1.5 \%$ \\
\hline $\begin{array}{l}\text { Convergion } \\
\text { Speed }\end{array}$ & medium & medium & Varies & Varies & Fast & Fast & Fast \\
\hline
\end{tabular}

\section{Conclusion}

An algorithm for modeling and Maximum Power Point (MPP) detection of a PV module has been developed. The proposed algorithm requires less information to get an accurate model and maximum power point. In this work, the proposed algorithm uses open circuit voltage and short circuit current only as input data. The initial values of the model parameters is estimated by extracting the panel parameters from datasheet values, and the obtained values have been used in the proposed algorithm. PV model and (MPP) are estimated using the Newton Raphson method. From the present analysis, one can draw the following main conclusions:

1- The proposed algorithm uses open circuit voltage and short circuit current only as input data.

2 The proposed algorithm give initial values of PV model and (MPP) sufficiently near the desired and the Newton-Raphson iterative method converges remarkably quickly.

3- The proposed equations which are expressed in a PV system, allow one to calculate a PV model parameters and (MPP) without relying on the experimental I-V.

4- It is seen that the accuracy of the estimated values of maximum power are in good tolerance for different manufacturer models shell SP75 model (mono-crystalline silicon and shell KC200GT model (multicrystal)

5- The calculated (I-V) curves based on the proposed method are in good agreement with the experimental data for different manufacturer models shell SP75 model (mono-crystalline silicon and shell KC200GT model (multicrystal). 


\section{References}

Abdelsalam, A. K., Massoud, A. M., Ahmed, S., \& Enjeti, P. N. 2011. High-performance adaptive perturb and observe MPPT technique for photovoltaic-based microgrids. IEEE Transactions on Power Electronics, Vol. 26, No. 4, pp. 1010-1021.

Arab, A. H., Chenlo, F., \& Benghanem, M. 2004. Loss-of-load probability of photovoltaic water pumping systems. Solar Energy, Vol. 76, No. 6, pp. 713-723.

Bazilian, M., Onyeji, I., Liebreich, M., MacGill, I., Chase, J., Shah, J., \& Zhengrong, S. 2013. Re-considering the economics of photovoltaic power. Renewable Energy, 53, pp. 329-338.

Bai, J., Liu, S., Hao, Y., Zhang, Z., Jiang, M., \& Zhang, Y. 2014. Development of a new compound method to extract the five parameters of PV modules. Energy Conversion and Management, Vol. 79, pp. 294-303.

Bai, J., Liu, S., Hao, Y., Zhang, Z., Jiang, M., \& Zhang, Y. 2014. Development of a new compound method to extract the five parameters of PV modules. Energy Conversion and Management, Vol. 79, pp. 294-303.

Bahgat, A. B. G., Helwa, N. H., Ahmad, G. E., \& El Shenawy, E. T. 2005. Maximum power point traking controller for PV systems using neural networks. Renewable Energy, Vol. 30, No. 8, pp. 1257-1268.

Carrero, C., Amador, J., \& Arnaltes, S. 2007. A single procedure for helping PV designers to select silicon PV modules and evaluate the loss resistances. Renewable Energy, Vol. 32, No. 15, pp. 2579-2589.

Celik, A. N., \& Acikgoz, N. 2007. Modelling and experimental verification of the operating current of mono-crystalline photovoltaic modules using four-and five-parameter models. Applied Energy, Vol. 84, No. 1, pp. 1-15.

Chegaar, M., Ouennoughi, Z., Guechi, F., \& Langueur, H. 2003. Determination of solar cells parameters under illuminated conditions. Journal of Electron Devices, Vol. 2, No. 2003, pp. 17-21.

Chun, S., \& Kwasinski, A. 2011. Analysis of classical root-finding methods applied to digital maximum power point tracking for sustainable photovoltaic energy generation. IEEE Transactions on Power Electronics, Vol. 26, No. 12, pp. $3730-3743$.

De Soto, W., Klein, S. A., \& Beckman, W. A. 2006. Improvement and validation of a model for photovoltaic array performance. Solar Energy, Vol. 80, No. 1, pp. 78-88.

Dondi, D., Bertacchini, A., Brunelli, D., Larcher, L., \& Benini, L. 2008. Modeling and optimization of a solar energy harvester system for self-powered wireless sensor networks. IEEE Transactions on Industrial Electronics, Vol. 55, No. 7, pp. 2759-2766.

Elshatter, T. F., Elhagree, M. T., Aboueldahab, M. E., \& Elkousry, A. A. 1997. Fuzzy modeling and simulation of photovoltaic system. In 14th European photovoltaic Solar Energy Conference on CD ROM.

Emmott, C., Azzopardi, B., Espinosa, N., Garcia-Valverde, R., Urbina, A., Mutale, J. \& Nelson, J. 2011. Economical assessment of solar electricity from organic photovoltaic systems.

El-Sayed, M. A., \& Leeb, S. 2014. Fuzzy logic based maximum power point tracking using boost converter for solar photovoltaic system in Kuwait. In International Conference on Renewable Energies and Power Quality (ICREPQ'14) (No. 12, pp. 1-12).

Enslin, J. H., Wolf, M. S., Snyman, D. B., \& Swiegers, W. 1997. Integrated photovoltaic maximum power point tracking converter. IEEE Transactions on Industrial Electronics, Vol. 44, No. 6, pp. 769-773.

Faranda, R., \& Leva, S. 2008. Energy comparison of MPPT techniques for PV Systems. WSEAS Transactions on Power Systems, Vol. 3, No. 6, pp. 446-455.

Huynh, D. C., Nguyen, T. A., Dunnigan, M. W., \& Mueller, M. A. 2013. Maximum power point tracking of solar photovoltaic panels using advanced perturbation and observation algorithm. In Industrial Electronics and Applications (ICIEA), 2013 8th IEEE Conference on (pp. 864-869). IEEE.

Hohm, D. P., \& Ropp, M. E. 2003. Comparative study of maximum power point tracking algorithms. Progress in Photovoltaics: Research and Applications, Vol. 11, No. 1, pp. 47-62.

Ishibashi, K. I., Kimura, Y., \& Niwano, M. 2008. An extensively valid and stable method for derivation of all parameters of a solar cell from a single current-voltage characteristic. Journal of Applied Physics, Vol. 103, No. 9, pp. 094507.

Jain, S., \& Agarwal, V. 2007. Comparison of the performance of maximum power point tracking schemes applied to single-stage grid-connected photovoltaic systems. IET Electric Power Applications, Vol. 1, No. 5, pp. 753-762.

Kok Soon, T., Mekhilef, S., \& Safari, A. 2013. Simple and low cost incremental conductance maximum power point tracking using buck-boost converter. Journal of Renewable and Sustainable Energy, Vol. 5, No. 2, pp. 023106.

Kannan, R., Leong, K. C., Osman, R., Ho, H. K., \& Tso, C. P. 2006. Life cycle assessment study of solar PV systems: an example of a $2.7 \mathrm{~kW}$ p distributed solar PV system in Singapore. Solar Energy, Vol. 80, No. 5, pp. 555-563.

Kamarzaman, N. A., \& Tan, C. W. 2014. A comprehensive review of maximum power point tracking algorithms for photovoltaic systems. Renewable and Sustainable Energy Reviews, Vol. 37, pp. 585-598.

Khezzar, R., Zereg, M., \& Khezzar, A. 2009. Comparative study of mathematical methods for parameters calculation of currentvoltage characteristic of photovoltaic module. In Electrical and Electronics Engineering, 2009. ELECO 2009. International Conference on (pp. 1-24). IEEE.

KC200GT photovoltaic solar module; http://www.kyocera.com.

López-Lapeña, O., Penella, M. T., \& Gasulla, M. 2010. A new MPPT method for low-power solar energy harvesting. IEEE Transactions on Industrial Electronics, Vol. 57, No. 9, pp. 3129-3138. 
Masson, G., Latour, M., Rekinger, M., Theologitis, I. T., \& Papoutsi, M. Global Market Outlook for Photovoltaics 2013-2017; European Photovoltaic Industry Association: Brussels, Belgium, 2013.

Ma, J., Man, K. L., Ting, T. O., Zhang, N., Guan, S. U., \& Wong, P. W. 2013. Dem: direct estimation method for photovoltaic maximum power point tracking. Procedia Computer Science, Vol. 17, pp. 537-544.

Mellit, A., Benghanem, M., \& Kalogirou, S. A. 2007. Modeling and simulation of a stand-alone photovoltaic system using an adaptive artificial neural network: Proposition for a new sizing procedure. Renewable Energy, Vol. 32, No. 2, pp. $285-313$.

Noguchi, T., Togashi, S., \& Nakamoto, R. 2002. Short-current pulse-based maximum-power-point tracking method for multiple photovoltaic-and-converter module system. IEEE Transactions on Industrial Electronics, Vol. 49, No. 1, pp. $217-223$.

Ramani, S. U., Kollimalla, S. K., \& Arundhati, B. 2017. Comparitive study of P\&O and incremental conductance method for PV system. In Circuit, Power and Computing Technologies (ICCPCT), 2017 IEEE International Conference on (pp. 1-7).

Roman, E., Alonso, R., Ibañez, P., Elorduizapatarietxe, S., \& Goitia, D. 2006. Intelligent PV module for grid-connected PV systems. IEEE Transactions on Industrial Electronics, Vol. 53, No. 4, pp. 1066-1073.

Sera, D., Mathe, L., Kerekes, T., Spataru, S. V., \& Teodorescu, R. 2013. On the perturb-and-observe and incremental conductance MPPT methods for PV systems. IEEE Journal of Photovoltaics, Vol. 3, No. 3, pp. 1070-1078.

Salam, Z., Ahmed, J., \& Merugu, B. S. 2013. The application of soft computing methods for MPPT of PV system: A technological and status review. Applied Energy, Vol. 107, pp. 135-148.

Sher, H. A., Murtaza, A. F., Noman, A., Addoweesh, K. E., Al-Haddad, K., \& Chiaberge, M. 2015. A new sensorless hybrid MPPT algorithm based on fractional short-circuit current measurement and P\&O MPPT. IEEE Transactions on Sustainable Energy, Vol. 6, No. 4, pp. 1426-1434.

Simjee, F. I., \& Chou, P. H. 2008. Efficient charging of supercapacitors for extended lifetime of wireless sensor nodes. IEEE Transactions on Power Electronics, Vol. 23, No. 3, pp. 1526-1536.

Shell SP75 photovoltaic solar module; http://www.shell.com/solar.

Villalva, M. G., Gazoli, J. R., \& Ruppert Filho, E. 2009. Comprehensive approach to modeling and simulation of photovoltaic arrays. IEEE Transactions on Power Electronics, Vol. 24, No. 5, pp. 1198-1208.

Walker, G. 2001. Evaluating MPPT converter topologies using a MATLAB PV model. Journal of Electrical \& Electronics Engineering, Vol. 21, No. 1, pp. 49-56.

\section{Biographical notes}

Mohamed Abd-El-Hakeem Mohamed was born in Egypt, Assiut in 1980. He received the B. Sc. and M. Sc. degrees from the Department of Electrical Engineering, Faculty of Engineering, Assiut University, Assiut, Egypt. He received the Ph. D. degree in electrical engineering, in 2012, from Al-Azhar University, Cairo, Egypt. He is currently with the Department of Electrical Engineering, Faculty of Engineering, Al-Azhar University, Qena, Egypt. His research interests are in the areas of power system control, modeling and control of renewable energy systems.

Almoataz Y. Abdelaziz received the B.Sc. and M.Sc. degrees in electrical engineering from Ain Shams University, Egypt, in 1985 and 1990 , respectively, and the $\mathrm{Ph} . \mathrm{D}$. degree in electrical engineering according to the channel system between Ain Shams University, Egypt, and Brunel University, U.K., in 1996. He is currently a Professor of electrical power engineering at Ain Shams University. Dr. Abdelaziz is the chair of IEEE Education Society chapter in Egypt, senior editor of Ain Shams Engineering Journal, editor of Electric Power Components \& Systems Journal, editorial board member, associate editor and editorial advisory board member of several international journals and conferences. He is also a member in IET and the Egyptian Sub-Committees of IEC and CIGRE'. He has been awarded many prizes for distinct researches and for international publishing from Ain Shams University, Egypt. He has authored or coauthored more than 320 refereed journal and conference papers in his research areas which include the applications of artificial intelligence, evolutionary and heuristic optimization techniques to power system operation, planning, and control.

Received July 2017

Accepted December 2017

Final acceptance in revised form March 2018 